\title{
高脂肪・高コレステロール食負荷による肝臓薬物代謝酵素への影響
}

\author{
鈴木祥菜，佐藤陽子，梅垣敬三，千葉 剛*
}

\section{Influence of High-fat and High-cholesterol Diet on Major CYP Activities in the Liver}

\author{
Sachina Suzuki, Yoko Sato, Keizo Umegaki, and Tsuyoshi Chiba* \\ Information Center, National Institute of Health and Nutrition, National Institutes of Biomedical Innovation, \\ Health and Nutrition; 1-23-1 Toyama, Shinjuku-ku, Tokyo 162-8636, Japan.
}

(Received March 31, 2016; Accepted May 20, 2016)

\begin{abstract}
We previously reported that a high-fat and high-cholesterol (HFHC) diet for 12 weeks induced non-alcoholic steatohepatitis (NASH) and influenced major CYP subtype gene expression levels and activities in a mouse model. In the present study, we determined the effects of the HFHC diet on CYP expression levels and activities prior to the establishment of NASH. When male C57BL/6J mice were fed the HFHC or a normal chow diet (Control) ad libitum for 4 weeks, body weights were significantly lower, whereas liver weights and hepatic lipid contents were significantly higher in the HFHC group than in the Control group. Under these conditions, hepatic microsomal luciferin-H (human CYP2C9 substrate) hydroxylation activity was significantly lower in the HFHC group than in the Control group. In order to investigate drug efficacy in mice fed the HFHC diet, an intraperitoneal glucose tolerance test was conducted with or without a pretreatment with tolbutamide (a CYP2C substrate) after 4 weeks of feeding. The plasma glucose-lowering effects of tolbutamide were attenuated in the HFHC group even though luciferin- $\mathrm{H}$ hydroxylation activity was suppressed in this group. The reason for this discrepancy was attributed to the mRNA expression levels of Cyp2c44 being lower and those of Cyp2c29 and Cyp2c66, which are involved in the metabolism of tolbutamide, being higher in the HFHC group than in the Control group. These results indicate that the expression of Cyp2c in the liver is influenced by the HFHC diet prior to the establishment of NASH and its regulation differed among the subtypes examined.
\end{abstract}

Key words - CYP; diet; fatty liver; non-alcoholic steatohepatitis; tolbutamide

序論

非アルコール性脂肪性肝疾患（non-alcoholic fatty liver disease; NAFLD)，さらには NAFLD が進 展した非アルコール性脂肪性肝炎（non-alcoholic steatohepatitis; NASH） は近年，世界中で広まって いる。 NASH は, 脂肪変性, 炎症, 肝細胞障害 （風船様変性）を特徵とし，将来的に肝硬変や肝が んを発症することが知られている. ${ }^{1,2}$

NASH の根本的な治療法は現在も確立しておら ず，食事や運動療法が中心となっている。しかしな がら, NASH 患者は肥満, 脂質代謝異常症, 糖尿 病などを罹患していることが多いため,これらの疾 患に対して薬物治療が行われる, 具体的には, 高脂

国立研究開発法人医薬基盤 ・健康 - 栄養研究所国立健

康・栄養研究所情報センター

*e-mail: tyschiba@nih.go.jp
血症治療薬（スタチンやプロブコールなど），イン スリン抵抗性改善薬（メトホルミンやチアゾリジン など)，血糖降下薬（トルブタミドなど）などが用 いられる。

肝臓は薬物代謝を行う主要な臓器であり, 薬物代 謝酵素である CYP が存在する，肝臓における脂肪 の蓄積や炎症は, 肝臓の機能に影響を及ぼし, CYP に影響することが報告されている. ${ }^{3-5)} \mathrm{NASH}$ においても, 種々のCYP の発現量や活性が変動す ることが報告されており, ${ }^{6-8)} \mathrm{NASH}$ 患者における CYP の変動は薬物治療への影響が懸念される.

肝臓の病態が CYP に影響を及ぼすことが明らか となっている一方で, 食事によってもCYP に影響 を及ぼすことが明らかとなってきている. 当研究室 でもマウスを用いた検討により通常食に比較し, 低 タンパク質食において Cyp3a 活性が有意に増加す

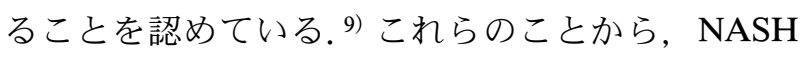
の病態が確立する以前より, NASH をもたらすよ 
うな食事自体が CYP 活性に影響を及ぼしている可 能性が示唆される.

マウスモデルにおいて，これまで種々の NASH 誘導食が用いられている。そ只中で，高脂肪・高コ レステロール・コール酸含有（high-fat and highcholesterol; HFHC）食は，肝臓の脂質蓄積，脂肪 変性，炎症，線維化だけでなく，細胞の風船様変性 を引き起こすことから，よりヒトの NASH に近い 病態を誘導することが報告されている. ${ }^{10,11)}$ われわ れは HFHC 食をマウスに 12 週間負荷し，NASH を誘導した際の医薬品の代謝に関連の深い主要な CYP について検討した。 その結果，NASH を発症 したマウスにおいて，肝臓におけるCyp1a1, 1a2， 3a 活性の亢進, Cyp2c 活性の減少を認めた. ${ }^{12)}$ しか しながら,この変動が NASH の病態が進行したた めによるものであるのか，それ以前から HFHC 食 の影響によるものであるのかは明らかとなっていな い.

そこで本研究では，NASH 発症前の状態におけ る HFHC 食の影響を検討するため, マウスに HFHC 食を 4 週間負荷した際の CYPへの影響を Cyp1a1, 1a2, 2c, 3a に焦点を当て検討を行った.

\section{実 験 方 法}

\section{1. 実験動物, 飼料 C57BL/6J (雄, 10 週齢)} （日本クレア株式会社）を 2 群（各 5 匹）に群分け, 一方に通常飼料（Control），もう一方に HFHC 食 （オリエンタル酵母工業株式会社）（Table 1）を与 え 4 週間飼育した。室温 $23 \pm 1^{\circ} \mathrm{C}, 12$ 時間の明暗开 イクルの環境で，飼料と水は自由に䎿取させ飼育を 行った。䬹は，月，水，金で補充を行った．飼育期 間終了後，一晚（前日の 17 時より）絶食を行い, イソフルラン麻酔下で心臓より全血採血を行った. 全身潅流を行った後, 肝臓を摘出, 直ちに凍結し た. 血液は遠心分離 $\left(3000 \mathrm{rpm}, 15\right.$ 分, $\left.4^{\circ} \mathrm{C}\right)$ 後, 血漿を採取した，血漿サンプル及び肝臓は測定に用 いるまでー $80^{\circ} \mathrm{C}$ にて保存した。動物実験は国立研 究開発法人医薬基盤 - 健康 - 栄養研究所実験動物倫 理委員会の承認を得て, 同委員会のガイドラインに 準じて行った.

2. 血液分析 血漿中のトリグリセリド (TG), 総コレステロール（TC），遊離脂肪酸（non-esterified fatty acids; NEFA), グルコース, asparagine
Table 1. Composition of Experimental Diets

\begin{tabular}{lcc}
\hline \hline & Control & HFHC \\
\hline Composition (wt/wt\%) & 100 & 38.25 \\
CRF-1 & - & 60 \\
Cocoa butter & - & 1.25 \\
Cholesterol & - & 0.5 \\
Cholate & & \\
Energy composition (/100 g) & 55.3 & 21.2 \\
Carbohydrate (g) & 21.9 & 8.4 \\
Protein (g) & 5.4 & 62.1 \\
Fat (g) & 357 & 677 \\
Total calorie (kcal) &
\end{tabular}

aminotransferase (AST), alanine aminotransferase (ALT), alkaline phosphatase (ALP) は，酵素法 （和光純薬工業株式会社，大阪）により測定を行っ た.

3. 肝臓脂質の測定 肝臓脂質は Folch 法に 従って抽出した。具体的には，Polytron ホモジナ イザーを用い，肝臓（約 $0.1 \mathrm{~g} ）$ を $6 \mathrm{~mL}$ クロロホ ルム/メタノール (2:1) 中でホモジナイズした. 一晚静置後, 濾過により不溶性の残渣を除き, クロ ロホルム／メタノールを加え $10 \mathrm{~mL}$ に調整した. 各サンプル $1 \mathrm{~mL}$ をマイクロチューブに分注し, 加 温して溶媒を除去後, 残留物をイソプロパノール （10\% Triton-X 含有）に再懸濁した。脂質量（TG， TC, NEFA）は酵素法（和光純薬工業株式会社）に より測定を行った.

4. 薬物代謝酵素活性の測定肝臓（約 $0.5 \mathrm{~g}$ ) を $0.25 \mathrm{M}$ sucrose 含有 $50 \mathrm{~mm}$ Tris- $\mathrm{HCl}$ buffer $(\mathrm{pH}$ 7.4）でホモジナイズ後， $10000 \times \mathrm{g}, 4^{\circ} \mathrm{C}, 30$ 分で 遠心，上清を採取し， $105000 \times \mathrm{g}, 4^{\circ} \mathrm{C}, 60$ 分で遠 心した。 上清を除去後，沈殿物を $50 \mathrm{mM}$ Tris- $\mathrm{HCl}$ buffer（pH 7.4）に再懸濁し，ミクロソーム調製液 とした。タンパク質濃度は Pierce BCA protein assay kit [サーモフィッシャーサイエンティフィック (株)，Rockford] を用い測定した。各 CYP 活性は, P450-Glo ${ }^{\text {TM }}$ CYP1A1 System (Luciferin-CEE) Assay, CYP1A2 System (Luciferin-1A2) Assay, CYP2C9 System (Luciferin-H) Assay, CYP3A4 System (Luciferin-PPXE) Assay, 及び NADPH Regeneration System を使用して, GloMax-Multi+ Detection System (Promega Co., Madison) にて蛍 光法により測定した。CYP 活性はタンパク質濃度 
Table 2. Primer Sequences $\left(5^{\prime}-3^{\prime}\right)$

\begin{tabular}{lll}
\hline \hline & \multicolumn{1}{c}{ Forward } & \multicolumn{1}{c}{ Reverse } \\
\hline GAPDH & TGATGCTGGTGCTGAGTATGTCGT & TCTCGTGGTTCACACCCATCACAA \\
Cypla1 & AGCTTGGCCTGGATTACTGT & AACCCCATCAACCCCAGTAG \\
Cypla2 & ACATCACAAGTGCCCTGTTCAAGC & ATCTTCCTCTGCACGTTAGGCCAT \\
Cyp2c29 & AGCCTACTGTCATATTGCACGGGT & CATGCCCAAATTTCGCAGGGTCAT \\
Cyp $2 c 39$ & CACAGCTAAAGTCCAGGAAGAG & TGAATCATGGCATCGGTATAGG \\
Cyp $2 c 44$ & GAGTTTCCCAACCCAGAGAAG & CGAGGGAGAAAGGAACAAAGTAG \\
Cyp $2 c 55$ & ACACACTGGCTGTTGCTATG & GTGAGAGGAGTAGTGAGAGAGATG \\
Cyp2c66 & GGTCTGGCTCGAACAGAATTA & CCATTGGCAACTGGAGTAGTAT \\
Cyp3a11 & AGGCAGAAGGCAAAGAAAGGCAAG & TGAGGGAATCCACGTTCACTCCAA \\
\hline
\end{tabular}

で補正し，コントロールに対する割合（\%）で示し た.

\section{CYP mRNA 発現量の測定肝臟より} TRIzol Plus RNA Purification System (Life Technologies，Carlsbad）を使用して Total RNA を抽出,

PrimeScript RT Master Mix（タカラバイオ株式会 社，草津）で cDNA 合成を行った。 SYBR Green PCR Master Mix及びThermal Cycler Dice Real Time System Single（タカラバイオ株式会社）を使 用し，各遺伝子に特異的なプライマー（Table 2) を用いて定量的 RT-PCR を行った。遺伝子の発現 量は，各プライマーを用いて作製した PCR 産物を 塩基配列よりコピー数を算出したスタンダードと し, 絶対定量法により各遺伝子発現のコピー数とし て算出した後, GAPDH に対する目的遺伝子の発 現量の割合で表した。

6. グルコース負荷試験（IPGTT） C57BL/ $6 \mathrm{~J}$ （雄，10 週齢）を 4 群（各 6 匹）に群分け, Control 食（2 群）又は HFHC 食（2 群）を与え， 4 週間飼育した。一晚（前日の 17 時より）絶食後, 各飼料の一方にトルブタミド（SIGMA, T0891,

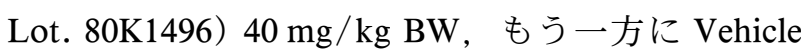
[大豆油 (10\% DMSO 含有)] を経口投与した. ${ }^{13)}$ トルブタミド投与 30 分後, すべての群にグルコー ス $2 \mathrm{~g} / \mathrm{kg} \mathrm{BW}$ を腹腔内投与した. グルコースの投 与 $-30,0,15,30,60,120,180$ 分後に尾部より採血 を行い, ブリーズ II（バイエル薬品株式会社）を 用い血糖値を測定した.

7. 統計処理 各データは平均值士標準誤差 (S.E.M.) で示した。統計処理はすべて Student $t$ test (PASW Statistics Base18, IBM, Armonk) で 行った. $p<0.05$ を有意差ありとした.
Table 3. Body and Tissue Weights of Mice after 4 Weeks

\begin{tabular}{lcc}
\hline \hline & Control & HFHC \\
\hline Body weight (g) & $23.2 \pm 0.44$ & $19.4 \pm 1.41^{*}$ \\
Liver (g) & $1.00 \pm 0.03$ & $1.24 \pm 0.08^{*}$ \\
Liver/BW (\%) & $4.31 \pm 0.08$ & $6.40 \pm 0.23^{* * *}$ \\
Kidney (g) & $0.29 \pm 0.01$ & $0.23 \pm 0.01^{* *}$ \\
Spleen (g) & $0.057 \pm 0.002$ & $0.046 \pm 0.004^{*}$ \\
Epididymal fat (g) & $0.31 \pm 0.03$ & $0.22 \pm 0.06$ \\
\hline
\end{tabular}

C57BL/6J mice were fed the control diet or HFHC diet for 4 weeks. Data are represented as the mean \pm S.E.M. $n=5$ in each diet. ${ }^{*} p<0.05$, ${ }^{* *} p<0.01,{ }^{* * *} p<0.001$ vs. control.

\section{結果}

\section{1. 体重, 各臓器重量及び血液分析 C57BL/} 6J マウス（雄，10 週齢）に HFHC 食あるいは Control 食を 4 週間与えた。体重は Control 群に比 較して HFHC 群で有意に低值を示し, 腎臓, 脾臓 重量も，HFHC 群で有意に低值を示した。一方， 肝臓重量及び体重当たりの肝臓重量の割合は HFHC 群で有意に高值を示しており, 肝臓の肥大 が確認された（Table 3)。肝臓の脂質含量を測定す ると, Control 群に比較して HFHC 群において, TG では差は認められなかったが，TC 及び NEFA で有意に高值を示した（Fig. 1).

血中の肝機能指標（AST, ALT, ALP）において Control 群に比較して HFHC 群において有意に高 值を示した（Table 4)．TC 量においても HFHC 群 で有意に高值を示したが，TG 及び NEFA 量にお いては有意に低值を示した（Table 4).

2. 肝臓 CYP mRNA 発現量及び CYP 活性 C57BL/6J マウス（雄，10 週齢）に HFHC 食あ るいは Control 食を 4 週間与えた後, 肝臓における 

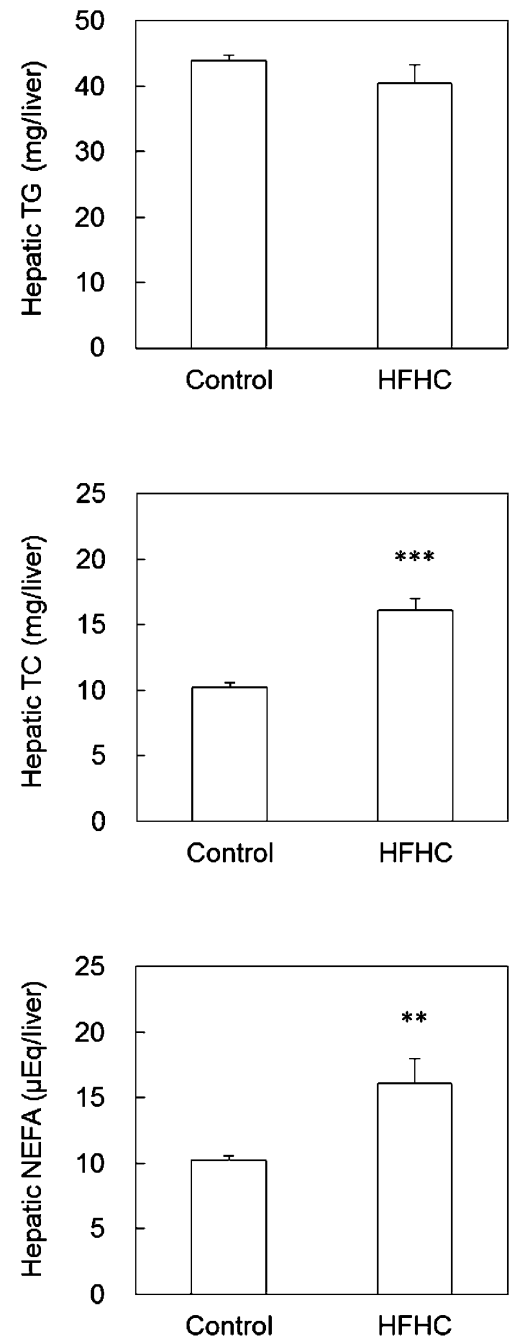

Fig. 1. Hepatic Lipid Contents

After experimental periods, lipids were extracted from the liver, and TG, TC and NEFA contents were measured by enzymatic methods. Data was represented the mean and S.E.M., $n=5$ in each diet. ${ }^{* *} p<0.01,{ }^{* * *} p<0.001$ vs. control.

Table 4. Plasma Biomarker Levels of Mice after 4 Weeks

\begin{tabular}{lcc}
\hline & Control & \multicolumn{1}{c}{ HFHC } \\
\hline AST (IU/L) & $57.3 \pm 6.7$ & $118.8 \pm 10.9^{* *}$ \\
ALT (IU/L) & $3.8 \pm 0.2$ & $23.6 \pm 3.1^{* *}$ \\
ALP (IU/L) & $55.8 \pm 1.6$ & $85.5 \pm 5.1^{* *}$ \\
TC (mg/dL) & $68.2 \pm 2.2$ & $82.1 \pm 5.5^{*}$ \\
TG (mg/dL) & $115.3 \pm 5.5$ & $27.8 \pm 1.4^{* * *}$ \\
NEFA (mEq/L) & $1.04 \pm 0.03$ & $0.79 \pm 0.08^{*}$ \\
Glucose (mg/dL) & $113.1 \pm 4.2$ & $124.8 \pm 7.7$ \\
\hline
\end{tabular}

C57BL/6J mice were fed the control diet or HFHC diet for 4 weeks. Data are represented as the mean \pm S.E.M. $n=5$ in each diet. ${ }^{*} p<0.05$, ${ }^{* *} p<0.01,{ }^{* * *} p<0.001 v$ s. control.

主要 CYP mRNA 発現量を測定した。その結果, Control 群に比較して HFHC 群で Cypla1, la2 mRNA 発現の増加傾向が認められ, Cyp2c29 及び
$3 a 11$ mRNA 発現の有意な増加が認められた [Fig. 2(A) ]。そこで，同肝臓よりミクロソーム画分を調 製したのち，CYP 活性を測定したところ，Control 群に比較して HFHC 群で luciferin-CEE（ヒト CYP1A1 基質) dechloroethylation 活性, luciferin1A2（ヒト CYP1A2 基質） demethylation 活性，luciferin-PPXE（ヒト CYP3A4 基質） dealkylation 活 性の増加傾向が認められ， luciferin-H（ヒト CYP2C9 基質）hydroxylation 活性の有意な低下が 認められた (Fig. 3).

Luciferin-CEE dechloroethylation 活性, luciferin1A2 demethylation 活性, luciferin-PPXE dealkylation 活性においては，マウスにおいて対応すると想 定される Cypla1, 1a2, 3al1 mRNA 発現と同様の 傾向を示していたものの, luciferin-H hydroxylation 活性に関しては，マウスにおいて対応すると想 定されるCyp2c29 mRNA 発現が充進しているにも かかわらず，その活性が低下していた。この原因を 調べるため，その他の Cyp $2 \mathrm{c}$ サブタイプについて も遺伝子発現を検討したところ, Control 群と比較 して HFHC 群において，Cyp2c39, 2c55 及び $2 c 66$ mRNA 発現において有意に六進若しくは六進傾向 を示した [Fig. 2(B)]. 一方, Cyp2c44の mRNA 発現量は有意に低値を示した [Fig. 2(B)]。この結 果より，HFHC 群における luciferin-H hydroxylation 活性の低下は，Cyp2c44 mRNA 発現量の低下 が影響している可能性が考えられた。

3. 糖負荷試験（IPGTT） HFHC 群において luciferin-H hydroxylation 活性が低下していたこと から，C57BL/6J マウス（雄， 10 週齢）に HFHC 食あるいは Control 食を 4 週間与えた後, トルブ夕 ミドの血糖低下作用への影響を IPGTT により検討 した.

Control 群においては, Vehicle 投与に比較し, トルブタミド投与によりグルコース負荷後の血糖值 の上昇が抑制され，AUCも有意に低值を示したこ とから，トルブタミドが作用していることが確認で きた [Fig. 4(A)]。一方，HFHC 群においては， トルブタミド投与による血糖の上昇抑制が認められ ず，また AUCにおいても，Vehicle と差が認めら れないことから，トルブタミドが作用していないこ とが認められた [Fig. 4(B)]. 
(A)
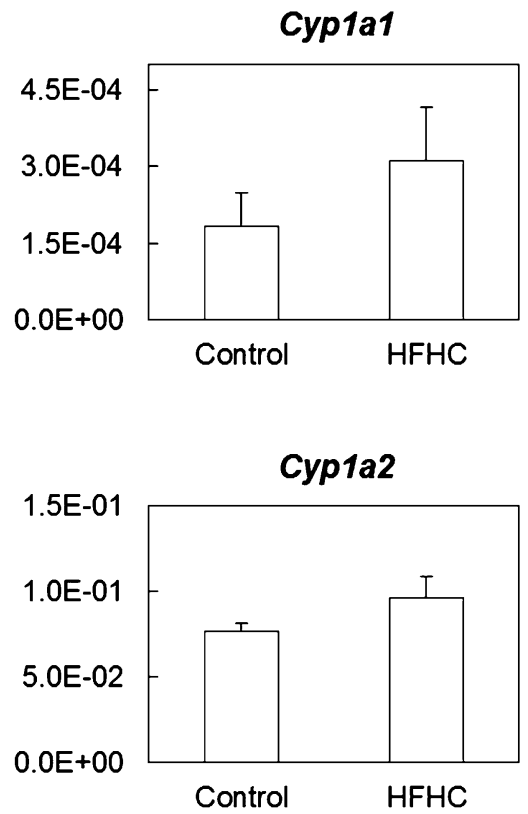

(B)

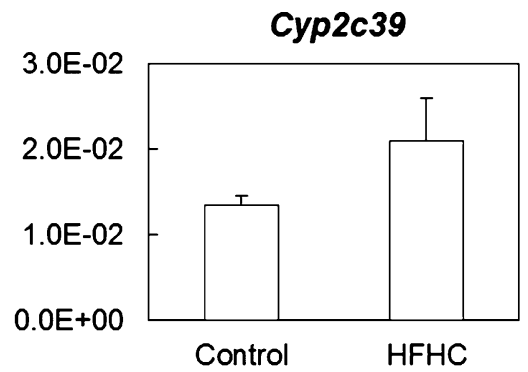

Cyp2c44

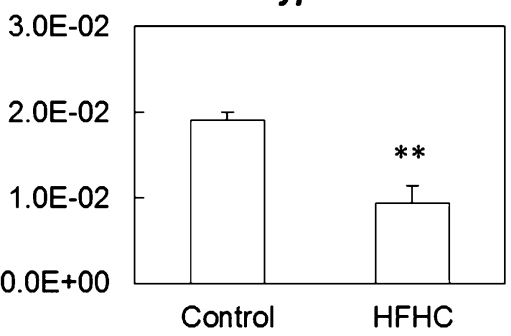

Cyp2c29

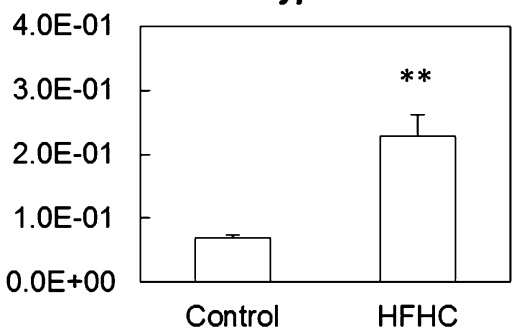

Cyp3a11

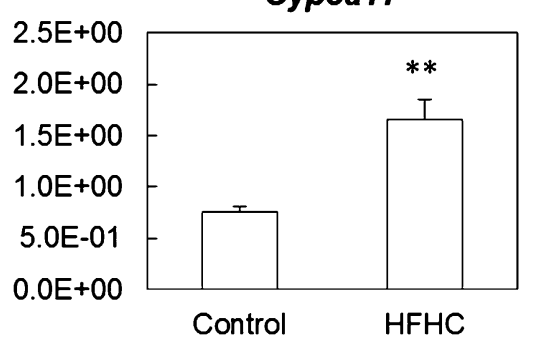

Fig. 2. CYP mRNA Expression Levels in Livers

Total RNA was extracted from the liver and mRNA expression levels of major CYP subtypes (A) and other Cyp2c subtypes (B) were measured by quantitative RT-PCR. Data was represented the mean and S.E.M., $n=5$ in each diet. ${ }^{* *} p<0.01 v s$. control.

考察

本研究では，NASH 発症前における HFHC 食に よるCYPへの影響についてマウスを用いて検討し た。本実験で用いた HFHC 食は NASH の特徵であ る肝臓の脂質蓄積, 脂肪変性, 炎症, 線維化, 細胞 の風船様変性などを引き起こし，マウスにおいてヒ
トの NASH に近い病態を誘導することが報告され ている. ${ }^{10,11)}$ この HFHC 食をマウスに 6 週間負荷 した実験では，肝臓脂質（TC, NEFA）の蓄積が認 められるが, 脂肪変性, 炎症, 線維化などの NASH の特徵において有意差は認められず, NASH 発症前の状態であることが報告されてい

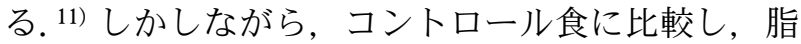



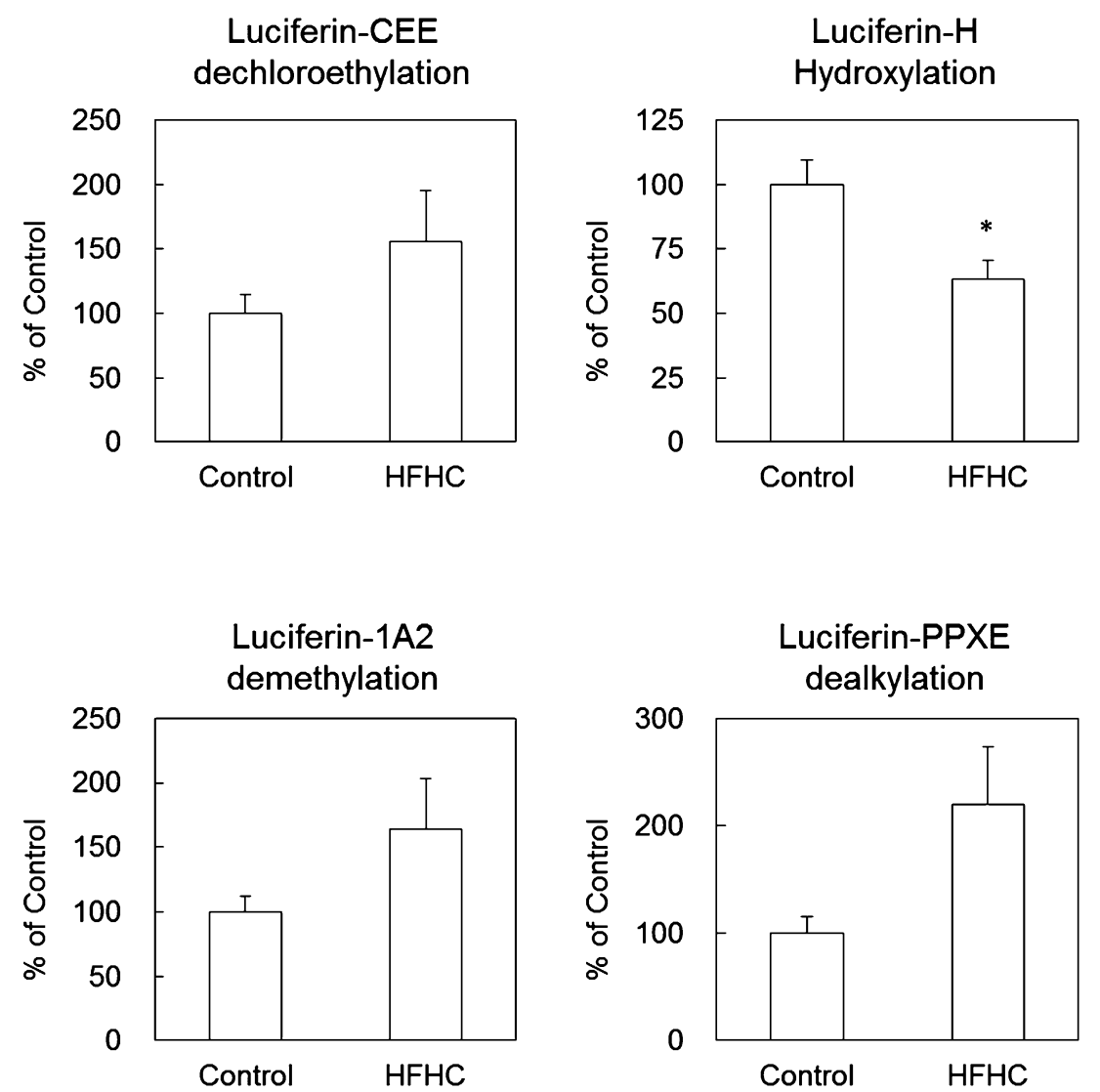

Fig. 3. Hepatic Microsomal CYP Activities

Microsomal fractions were prepared from the liver, and the activities of major CYP subtypes were measured by a luminescent method. Luciferin-CEE; human CYP1A1 substrate, luciferin-1A2; human CYP1A2 substrate, luciferin-H; human CYP2C9 substrate, luciferin-PPXE; human CYP3A4 substrate. Data was represented the mean and S.E.M., $n=5$ in each diet. ${ }^{*} p<0.05 v s$. control.

肪変性，炎症，線維化のいずれにおいても，若干， 高値を示していたことから，本研究においては, 6 週間よりも短い 4 週間で検討を行った。その結果, HFHC 食 4 週間負荷において, luciferin-H（ヒト CYP2C9 基質）hydroxylation 活性の有意な低下が 認められたにもかかわらず，トルブタミドの薬効の 減弱が認められた.

HFHC 食による CYP の変動にはいくつかの原因 が考えられる.

肝臓の CYP は化学物質や内在性基質の代謝に関 与しているが，肝疾患を有する患者においてこの作 用が影響される。ヒトにおいては CYP2C9, 2D6, 2E1 は肝疾患の影響を受け難いが, CYP1A, 2C19, 3A は影響を受け易いとされる. ${ }^{14)}$ また CYP の変動 パターンは, 肝疾患の病因に応じて異なることが報 告されている. ${ }^{14)}$ 本実験において，HFHC 食 4 週間 負荷において，AST, ALT, ALPが高值を示してお り，肝機能が悪化し始めていることが示唆される.
本研究において認められた CYP の変動は，この肝 機能の悪化が原因の 1 つと考えられる.

また，タンパク質の摂取量が原因している可能性 もある. HFHC4 週間負荷後の体重は Control 群に 比較して HFHC 群で有意に低值を示し，この体重 減少は少ない夕ンパク質摂取が原因と考えられ

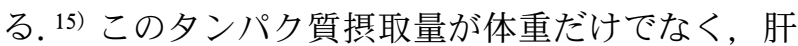
臓の CYP 活性に影響している可能性も示唆され る. 当研究室でコントロール食と高脂肪食若しくは 高タンパク質食を比較した場合，主要肝ミクロソー ム CYP 活性に差は認められなかったものの，コン トロール食と低タンパク質食を比較した場合, 低夕 ンパク質食で CYP 活性の亢進が認められている. ${ }^{9}$ しかしながら，低タンパク質食では肝臟重量も低下 しており，タンパク質摂取量の影響を示すには更な る検討が必要である。

HFHC 食により Cyp2c 活性の指標として測定し た luciferin-H hydroxylation 活性は低下していたこ 
(A)
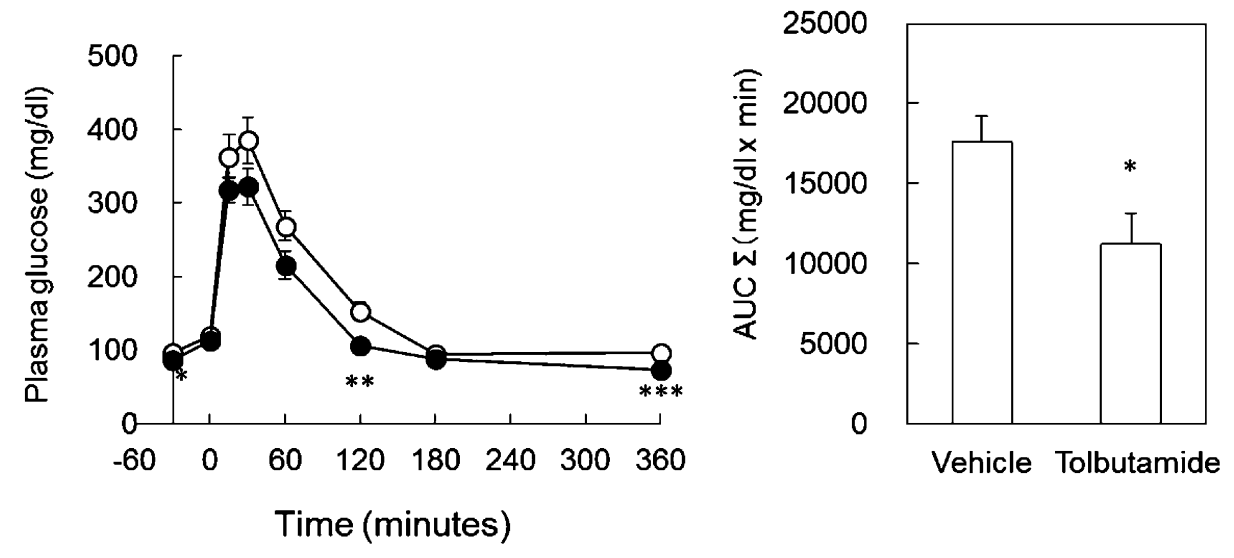

(B)
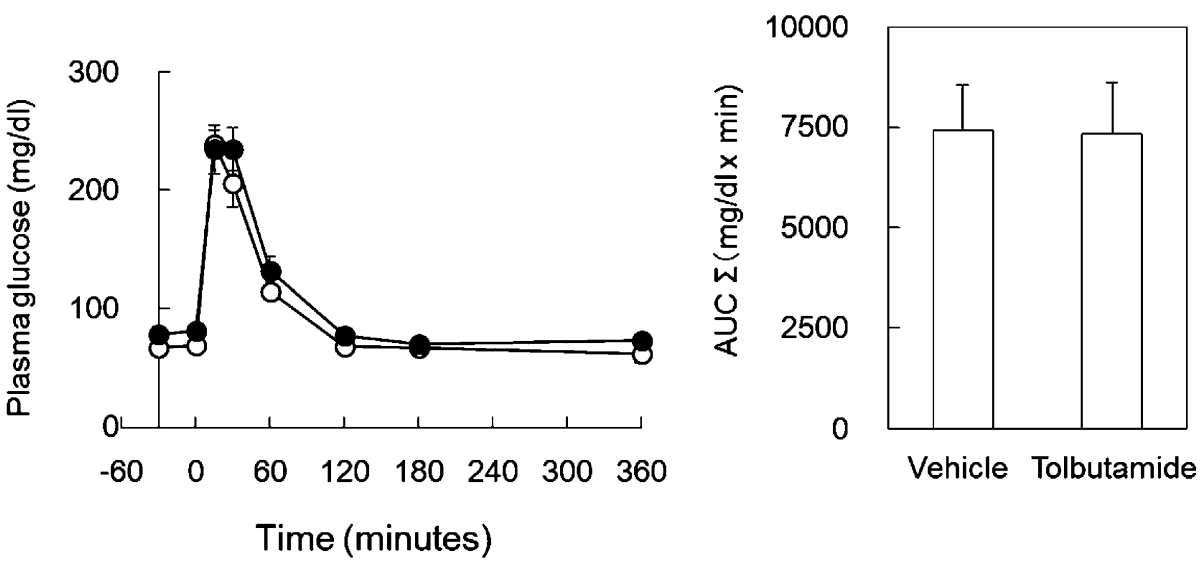

Fig. 4. Influences of HFHC Diet on the Efficacy of Tolbutamide

Mice were fed control (A) or HFHC (B) diet for 4 weeks. After overnight fasting, tolbutamide was administered (p.o. $40 \mathrm{mg} / \mathrm{kg} \mathrm{BW}$ ), then plasma glucose levels were measured after glucose administration (i.p. $2 \mathrm{~g} / \mathrm{kg} \mathrm{BW}$ ). The area under the curve for plasma glucose during the 180-min period after glucose administration was calculated. $\bigcirc$ : vehicle, $\bullet$ : tolbutamide. Values are means \pm S.E.M., $n=6 .{ }^{*} p<0.05,{ }^{* *} p<0.01,{ }^{* * *} p<0.001 v s$. vehicle.

とから，トルブタミドによる血糖低下作用が進し ていることを予想して IPGTT を行ったが，予想に 反してトルブタミドによる血糖低下作用は減弱され ていた．この原因としていくつか考えられる．本実 験で用いた CYP 活性の測定はヒト CYP 活性用の 試薬であるため, マウスにおいては他のタイプ若し くはサブタイプ活性が影響している可能性を否定で きない。また，HFHC 食により luciferin-H hydroxylation 活性は低下している一方で，HFHC 食では肝臓が肥大していることから，個体レベルで の総 luciferin-H hydroxylation（若しくは Cyp2c） 活性は低下していない可能性がある。しかしながら, HFHC 食による肝臓の肥大率は約 20\%であるのに
対して, luciferin-H hydroxylation 活性の低下は約 $35 \%$ であったことから，トルブタミドの薬効の減弱 を説明できない。トルブタミドは，ヒトにおいて CYP2C8，2C9，2C19 で代謝されるが，主に CYP2C9 が代謝に寄与している. ${ }^{16-18)}$ これはヒトの 肝臓ミクロソーム中の $\mathrm{CYP} 2 \mathrm{C}$ サブファミリーの各 平均量の違いが関連し, ${ }^{19)}$ CYP2C9に比較して CYP2C8 で代謝されるトルブタミド量は $1 / 3$ より 少なく, CYP2C19 で代謝される量はそれよりもさ らに少ないとされている。 ${ }^{18)}$ 本研究においては, HFHC 食により Cyp2c29, 2c39, 2c55, 2c66 mRNA 発現が充進しており，このうち，Cyp2c29，2c39 は ヒト CYP2C8 とホモロジーが高く, ${ }^{20)}$ Cyp2c66 は 
ヒト CYP2C9 とホモロジーが高いため, 21) マウス においては Cyp2c29, 2c39, 2c66 がトルブタミドの 代謝に関与していると考えられる。実際に Cyp2c29 及び 2c39 がトルブタミドの代謝に寄与していると いう報告があるが, ${ }^{22}$ 現時点で Cyp2c66に関する報 告はなく，いずれのサブタイプの関与が大きいのか は，更なる検討が必要である.

トルブタミドの血糖低下作用の減弱が CYP の活 性化を介したものではない可能性も否定できない. トルブタミドは膵 $\beta$ 細胞を刺激してインスリンの 分泌を促進することにより血糖を低下させる，つま り，HFHC 食によりインスリンの分泌能が障害を 受けていたり，インスリン感受性が低下している可 能性も考えられる。これまでに，マウス ${ }^{23,24)}$ 及びヒ 卜25,26)において高脂肪食の摂取は短期間においても インスリン抵抗性をもたらすことが示されている. これらの報告では，血中のインスリンレベルは一致 してコントロールよりも高值を示していることか ら，インスリン分泌能が障害されているのではな く，末梢におけるインスリン感受性が低下し，その 代償としてインスリン分泌が充進していることが示 されている，本研究においても HFHC 食によるト ルブタミドの薬効の減弱は末梢のインスリン感受性 の低下による可能性も考えられる。本研究結果が CYP の活性化を介したものであるかを明らかにす るためには，肝ミクロソームを用いてトルブタミド の代謝活性を算出することで推測ができるかもしれ ない.しかしながら，in vivo での動態を把握する にはトルブタミドの血中濃度を測定し，実際にトル ブタミドの代謝が充進しているかどうかを明らかと しなければならない。本研究においては，あくまで 薬物代謝酵素への影響を検討することを目的として おり，CYP の遺伝子発現量や活性に着目している ため, 薬物の血中動態を検討することは今後の課題 とする.

本研究結果はあくまでマウスでの検討であること を考慮しなくてはならない，前述のように，マウス とヒトでは CYP サブタイプ自体が異なっている. マウスではヒトと異なる様々なサブタイプが存在し ており，さらに，その挙動はサブタイプ毎に異なつ ており，ヒトにおいては NAFLD 進行とともに CYP2C9 の mRNA 発現量及び活性が増加し, 反対 にCYP2C19 の mRNA 発現量及び活性が低下する
ということが報告されている. ${ }^{8)}$ このことからも CYP 活性への影響を検討するには，種差だけでな く，サブタイプまで考慮しなければならない。ま た，肝臓の脂質に着目した場合，Control 群に比較 して HFHC 群において, 肝蔵 TC 量, NEFA 量が 有意に高値を示しているが，肝臟 TG 量については 2 群の間で有意差はない (Fig. 1)。本実験の結果は,

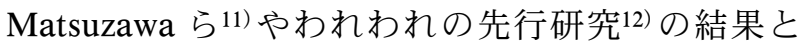
一致するが，ヒトの NASH 患者では主に TG が蓄 積されることから本研究結果を当てはめる上で考慮 しなければならない点の 1 つである。しかしなが ら，薬物への影響をヒトで試験することは難しく， マウス等のモデルを用いた推定は今後も必要であろ う.

本研究結果より, 脂肪やコレステロールの多い食 事により，薬物代謝酵素さらには薬効に影響を及ぼ すことが示唆された．脂肪やコレステロールの多い 食事は高脂血症を招くと同時に，肝臓における薬物 代謝酵素に影響を与え，その治療薬に影響を及ぼす ことが予想される，高脂血症を始めとする生活習慣 病は NASHへの進展をもたらすことから，医薬品 を服用している患者においてその治療薬が適切に作 用しているか注意が必要である.

謝辞本研究に関して有益なご指導, ご助言を 賜りました昭和女子大学生活科学部，横谷馨倫博士 に深く感謝いたします。

利益相反＼cjkstart開示すべき利益相反はない.

\section{REFERENCES}

1) Ludwig J., Viggiano T. R., McGill D. B., Oh B. J., Mayo Clin. Proc., 55, 434-438 (1980).

2) Sheth S. G., Gordon F. D., Chopra S., Ann. Intern. Med., 126, 137-145 (1997).

3) Leclercq I., Horsmans Y., Desager J. P., Delzenne N., Geubel A. P., J. Hepatol., 28, 410416 (1998).

4) Gómez-Lechón M. J., Jover R., Donato M. T., Curr. Drug Metab., 10, 692-699 (2009) .

5) Moriya N., Kataoka H., Fujino H., Nishikawa J., Kugawa F., Biol. Pharm. Bull., 35, 473-480 (2012).

6) Yamazaki Y., Kakizaki S., Horiguchi N., So- 
hara N., Sato K., Takagi H., Mori M., Negishi M., Gut, 56, 565-574 (2007).

7) Fisher C. D., Jackson J. P., Lickteig A. J., Augustine L. M., Cherrington N. J., Arch. Toxicol., 82, 959-964 (2008).

8) Fisher C. D., Lickteig A. J., Augustine L. M., Ranger-Moore J., Jackson J. P., Ferguson S. S., Cherrington N. J., Drug Metab. Dispos., 37, 2087-2094 (2009).

9) Yokotani K., Chiba T., Sato Y., Nakanishi T., Murata M., Umegaki K., J. Nutr. Sci. Vitaminol. (Tokyo), 59, 37-44 (2013).

10) Jeong W. I., Jeong D. H., Do S. H., Kim Y. K., Park H. Y., Kwon O. D., Kim T. H., Jeong K. S., J. Vet. Med. Sci., 67, 235-242 (2005).

11) Matsuzawa N., Takamura T., Kurita S., Misu H., Ota T., Ando H., Yokoyama M., Honda M., Zen Y., Nakanuma Y., Miyamoto K., Kaneko S., Hepatology, 46, 1392-1403 (2007).

12) Suzuki S., Sato Y., Umegaki K., Chiba T., Endocrinol. Metab. Syndr., 4, 1-6 (2015) .

13) Yokotani K., Chiba T., Sato Y., Umegaki K., Food Hyg. Saf. Sci., 55, 73-78 (2014).

14) Villeneuve J. P., Pichette V., Curr. Drug Metab., 5, 273-282 (2004).

15) Du F., Higginbotham D. A., White B. D., J. Nutr., 130, 514-521 (2000).

16) Srivastava P. K., Yun C. H., Beaune P. H., Ged C., Guengerich F. P., Mol. Pharmacol., 40, 69-79 (1991).

17) Veronese M. E., Doecke C. J., Mackenzie P. I., McManus M. E., Miners J. O., Rees D. L., Gasser R., Meyer U. A., Birkett D. J., Biochem. J., 289, 533-538 (1993).

18) Komatsu K., Ito K., Nakajima Y., Kanamitsu S., Imaoka S., Funae Y., Green C. E., Tyson
C. A., Shimada N., Sugiyama Y., Drug Metab. Dispos., 28, 475-481 (2000).

19) Imaoka S., Yamada T., Hiroi T., Hayashi K., Sakaki T., Yabusaki Y., Funae Y., Biochem. Pharmacol., 51, 1041-1050 (1996).

20) The National Center for Biotechnology Information (NCBI) HomoloGene Datebase. "CYP2C8": 〈http://www.ncbi.nlm.nih.gov/ homologene/117948〉, cited 15 March, 2016.

21) The National Center for Biotechnology Information (NCBI) HomoloGene Datebase. "CYP2C9": 〈http://www.ncbi.nlm.nih.gov/ homologene/133566〉, cited 15 March, 2016.

22) DeLozier T. C., Tsao C. C., Coulter S. J., Foley J., Bradbury J. A., Zeldin D. C., Goldstein J. A., J. Pharmacol. Exp. Ther., 310, 845-854 (2004).

23) Lee Y. S., Li P., Huh J. Y., Hwang I. J., Lu M., Kim J. I., Ham M., Talukdar S., Chen A., Lu W. J., Bandyopadhyay G. K., Schwendener R., Olefsky J., Kim J. B., Diabetes, 60, 2474-2483 (2011).

24) Kahle M., Schäfer A., Seelig A., Schultheiß J., Wu M., Aichler M., Leonhardt J., Rathkolb B., Rozman J., Sarioglu H., Hauck S. M., Ueffing M., Wolf E., Kastenmueller G., Adamski J., Walch A., Hrabé de Angelis M., Neschen S., Mol. Metab., 4, 39-50 (2015).

25) Brøns C., Jensen C. B., Storgaard H., Hiscock N. J., White A., Appel J. S., Jacobsen S., Nilsson E., Larsen C. M., Astrup A., Quistorff B., Vaag A., J. Physiol., 587, 23872397 (2009).

26) Bisschop P. H., de Metz J., Ackermans M. T., Endert E., Pijl H., Kuipers F., Meijer A. J., Sauerwein H. P., Romijn J. A., Am. J. Clin. Nutr., 73, 554-559 (2001). 